\title{
DA RELAÇÃo CORPO-ALMA À MENTE-CÉREBRO: A ANTROPOLOGIA CRISTÃ E AS NOVAS ANTROPOLOGIAS
}

The body-soul relationship to mind-brain: the christian antropologia and new antropologias

Renato Alves de Oliveira *

RESUMO: O objetivo deste artigo é mostrar que a questão referente aos dois princípios metafísicos constitutivos da antropologia cristã, o corpo/matéria e a alma/espírito, e a forma de conceber a relação entre eles encontra-se presentes no subsolo das novas antropologias materialistas, mas com um novo verniz através da relação entre a mente e o cérebro. Para a antropologia cristã, a existência do binômio corpo-alma é uma questão resolvida. As discussões se concentram na forma de conceber a relação entre ambos os princípios. Analogamente, para algumas antropologias materialistas atuais, a existência da mente e do cérebro é uma questão fechada. Os confrontos encontram-se na forma de conceber as relações entre a mente e o cérebro: há uma identificação ou distinção entres ambas as realidades? A mente seria uma qualidade emergente do cérebro?

PALAVRAS-CHAVE: Antropologia, Corpo, Alma, Mente, Cérebro.

ABSTRACT: The purpose of this article is to show that the question concerning the two constituent metaphysical principles of Christian anthropology, body/matter and soul/spirit, and the way of conceiving the relationship between them is present in the basement of the new materialist anthropologies, but with a new varnish through the relationship between mind and brain. For Christian anthropology, the existence of the binomial soul/body is a settled issue. The discussions focus on how to design the relationship between the two principles. Similarly, for some current materialistic anthropologies, the existence of the mind and the brain is a closed question. The clashes are the way of conceiving the relationship between mind and brain: Is there an identification or a distinction between the two realities? Would be the mind an emergent quality of the brain?

KEYWORDS: Anthropology, Body, Soul, Mind, Brain.

\footnotetext{
* Professor adjunto do departamento de teologia da PUC Minas. Artigo submetido a avaliação em 28.04.2014 e aprovado para publicação em 27.05.2014.
} 


\section{Introdução}

$\longrightarrow$ uem é o ser humano? Quais são os princípios que compõem a constituição ontológica do ser humano? O ser humano é uma magnitude unidimensional (só matéria/corpo ou só espírito/alma) ou bidimensional (corpo/matéria e espírito/alma)? Há uma supremacia de um princípio em relação ao outro? Que tipo de relação vigora entre o corpo e a alma? Entre estes dois princípios ontológicos, há uma relação conflitiva ou harmônica? As noções de corpo e de alma podem ser remodeladas em seu conteúdo semântico? Pode-se dizer que quando as antropologias materialistas atuais tratam da relação mente-cérebro não estariam, sutilmente, refletindo sobre a relação corpo-alma? A mente se identifica ou se distingue do cérebro humano? O que significa afirmar que o ser humano tem uma dimensão onto-axiológica? Por que o ser humano se distingue do mundo material que o circunda?

Na visão da antropologia cristã, o ser humano é constituído por dois princípios ontológicos (corpo e alma) entre os quais vigora uma relação de comunhão e de reciprocidade. A questão referente à existência de duas dimensões que compõem o ser humano continua presente em algumas antropologias atuais (teoria da identidade psiconeural, materialismo emergentista, dualismo interacionista e teoria da inteligência artificial), mas uma nova roupagem: a mente e o cérebro. A discussão consiste no tipo de relação vigente entre a mente e o cérebro: identificação, emergente ou distinção? A constatação da existência de duas dimensões presentes no ser humano é uma questão resolvida. $\mathrm{O}$ ponto de desencontro consiste no modo de conceber a relação que há entre as duas dimensões.

\section{Uma breve história teológica da relação corpo-alma}

\subsection{A relação corpo-alma na teologia patrística}

Na visão bíblica, o ser humano é criado por Deus como uma unidade na pluralidade de suas dimensões (basar, nesef e ruah). Cada vocábulo da antropologia bíblica não corresponde a um aspecto, mas responde pela uni-totalidade do ser humano. Assim, o ser humano, na sua totalidade, não tem, mas é basar, nesef e ruah. A condição de imagem de Deus não se refere a uma dimensão do ser humano, mas é imputada à sua totalidade psicofísica (WOFF, 1975, p. 17-85). O ser humano é criado, na sua totalidade psicofísica, à imagem que Deus tem de si mesmo. O ser criado todo por Deus está, também, na sua totalidade, destinado à participar da vida pós-mortal. Desta forma, há uma unidade entre a antropologia e a escatologia bíblicas. 
A afirmação de que o ser humano constitui uma unidade anímico-corpórea é um dado antropológico inabdicável para a fé cristã. No entanto, esta verdade irrenunciável foi objeto de árduos debates no curso da história do pensamento cristão. Para os autores cristãos dos primeiros séculos (patrística), foi um desafio fazer a passagem da visão unitária da antropologia bíblica para o cenário cultural greco-latino, marcado pela influência da filosofia platônica e da gnose. A visão antropológica do panorama cultural pós-bíblico estava impregnado de ideias como: a alma é divina, a pré-existência e imortalidade natural da alma; a relação dicotômica entre o corpo e a alma; uma visão pejorativa do corpo e, consequentemente, uma sobrevalorização da alma. A inculturação da antropologia bíblica neste contexto antropológico exigiu muita perspicácia reflexiva dos autores cristãos para não macularem as verdades basilares sobre o ser humano (integralidade antropológica, unidade pluridimensional etc.).

A penetração do gnosticismo no pensamento cristão representava um risco para as verdades centrais da fé: encarnação do Verbo, salvação pela mediação da morte de Cristo e a ressurreição dos mortos. Assim, a antropologia, a cristologia, a soteriologia e a escatologia precisavam ser blindadas da sedução gnóstica. Uma meditação sobre os mistérios da vida e da obra de Jesus Cristo proporcionavam um resgate da dimensão corpórea do ser humano, impedindo-o de ser visto somente em sua condição anímica. $\mathrm{O}$ corpo está relacionado com aquelas verdades nucleares da fé cristã. Por isso, os autores cristãos dos quatro primeiros séculos alertavam, com muita lucidez, sobre o perigo, para a fé cristã, da rejeição da condição corpórea na compreensão do ser humano. Uma visão puramente espiritualista do ser humano afeta frontalmente estas verdades nucleares. No fundo, procurava-se uma compreensão correta a respeito de quem é o ser humano, como se dá nele a relação corpo-alma, para depois entender quem é Cristo.

Com o escopo de salvaguardar as verdades cristãs nucleares do influxo gnóstico, a patrística defende a dignidade do corpo como elemento constituinte da unidade e totalidade antropológicas. O corpo não é um aspecto adicional, provisório, marginal e desprezível da constituição ontológica humana. O ser humano não pode ser definido exclusivamente pela sua dimensão anímica. A alma não é sinônimo e nem responde pela totalidade do ser humano. Ela se refere, assim como o corpo, a uma dimensão do ser humano. $\mathrm{O}$ corpo não é um receptáculo e nem o cárcere da alma. $\mathrm{O}$ ser humano não é somente corpo e nem somente alma, mas uma unidade de corpo e alma. A respeito destes dois aspectos ontológicos, um não pré-existe ao outro e nem entre eles vigora uma relação de subordinação ou piramidal, mas de comunhão e de unidade.

A reivindicação do aspecto corpóreo (tendência filo-somática), como elemento integrante da constituição do ser humano, é patrocinada principalmente pelos padres apologistas (Justino e Taciano) e pela escola an- 
tioquena (Irineu de Lião e Tertuliano). A dignidade do corpo é defendida diante de um cenário hostil à matéria, ao mundano e à carne. A apologia do corpo está vinculada a uma valorização da matéria e, também, no plano cristológico, da encarnação, da dimensão humana e histórica de Jesus Cristo e de sua mediação salvífica. Esta valorização do aspecto corpóreo, para compreender quem é o ser humano, não é seguida pela escola alexandrina (Clemente Alexandrino e Orígenes), em virtude de sua tendência platonizante (filo-psíquica). Esta escola advoga uma primazia da alma sobre o corpo. Esta tendência exerceu um influxo determinante no pensamento cristão ocidental. No horizonte da escola alexandrina, a alma é vista como o elemento excelso, a melhor parte, a dimensão que define e especifica quem é o ser humano. Este primado da alma é radicalizado por Orígenes que defende a pré-existência, a imortalidade natural e a encarnação provisória devido à queda do mundo celeste (caráter medicinal) e o retorno ao estado desencarnado da alma. As teses de Orígenes foram condenadas pelo sínodo de Constantinopla, em 543 (RUIZ DE LA PEÑA, 1988, p. 94-98; LADARIA, 2003, p. 89-100).

O primado da alma sobre o corpo, também, é defendido por Agostinho (354-430), para quem o ser humano é um composto de corpo e alma racional. “O homem não é nem só corpo nem só alma, mas um composto de corpo e de alma. É certamente verdade que a alma não é o homem todo, mas sua melhor parte; nem o corpo é o homem todo, mas sua parte inferior: são os dois reunidos que merecem o nome de homem" (AGOSTINHO, XIII, 24, 2). O bispo de Hipona defende, simultaneamente, uma supremacia da alma e a sua união com o corpo. A alma, como imagem do Deus trino, consiste na essência do ser humano. Da união entre o corpo e a alma emerge uma "grande maravilha incompreensível ao homem: é o homem" (AGOSTINHO, XXI, 10, 1). Entre ambos os componentes constituintes do ser humano vigora uma relação hierárquica. A alma, considerada a parte mais nobre do composto humano, exerce um domínio sobre o corpo. Este é visto como um instrumento e está subordinado à alma. No horizonte agostiniano, a relação entre o corpo e a alma é "entendida mais como funcional e acidental do que substancial" (FIORENZA; METZ, 1973, p. 48). O corpo, como espaço de manifestação do pecado, está a serviço da alma racional. É a alma que direciona e rege o corpo. O pecado é visto como o fator que desarmoniza a relação entre o corpo e a alma. O corpo pode se rebelar contra a alma e conduzir a vontade para o mal. Apesar do corpo ser concebido como a parte ínfima do composto humano, não se registra, em Agostinho, um olhar repugnante e nem negativista para com o mesmo, porque é criado por Deus. O corpo e a alma são duas dimensões distintas, não contrárias ou opostas, mas necessárias para a constituição do ser humano.

As declarações magisteriais do período patrístico que tratam da composição humana (corpo-alma) foram feitas em um contexto cristológico e não 
propriamente antropológico. No contexto das controvérsias cristológicas, a patrística aprofunda suas reflexões sobre a estrutura do composto humano. Com o intento de afirmar a verdadeira humanidade de Cristo, a patrística advoga que o homem consiste numa carne animada por uma alma racional (FLICK; ALSZEGHY, 1999, p. 141). Tratando das declarações conciliares sobre o ser humano na patrística, Ladaria (2003, p. 107) denota que "quando os concílios cristológicos afirmam a plena humanidade de Jesus, indica que ele assumiu uma alma racional e um corpo, o que quer dizer indiretamente que os dois constituem o homem completo". Segundo o concílio de Éfeso (431), a natureza do Verbo "não foi transformada em um homem completo composto de alma e corpo", mas uniu a si, por hipóstase, "uma carne animada por uma alma racional e veio a ser homem" (DENZINGER; HÜNERMANN, 2007, n. 250). O símbolo da Fórmula de união (433) declara que Jesus é "perfeito Deus e homem perfeito composto de alma racional e de corpo" (DENZINGER; HÜNERMANN, 2007, n. 272). Em sintonia com a Fórmula de união, o concílio de Calcedônia (451) afirma que Jesus Cristo é "perfeito na sua divindade e perfeito na sua humanidade, verdadeiro Deus e verdadeiro homem composto de alma racional e corpo" (DENZINGER; HÜNERMANN, 2007, n. 301).

Os autores cristãos e as declarações magisteriais que trataram, direta ou indiretamente, do ser humano, até o presente momento, estavam mais preocupados em detectar quais elementos compõem a sua constituição ontológica do que propriamente em estabelecer que tipo de relação vige entre o corpo e a alma (justaposição? união acidental? união substancial?). A busca em precisar a natureza da relação que há entre ambos os elementos constitutivos do composto humano será a preocupação da teologia medieval.

\subsection{A relação corpo-alma na teologia medieval}

No período patrístico, a antropologia cristã estava em função da cristologia. Já no período medieval a antropologia cristã se situa no horizonte escatológico. "Foi a determinação cristológica da antropologia que na época patrística ditou a recuperação do corpo na compreensão do humano; agora será a escatologia [...] que determinará a consideração da unidade substancial corpo-alma" (RUIZ DE LA PEÑA, 1988, p. 102). Os teólogos medievais quando indagam sobre a essência humana estão movidos por um interesse escatológico. Se, com a morte, a alma se separa do corpo, então é preciso interpelar: que tipo de união (acidental ou substancial?) há entre o corpo e a alma? Neste contexto, é pertinente perguntar: a salvação está destinada a qual sujeito? À alma imortal que se separou do corpo com a morte ou ao ser humano todo? Pode-se, ainda, indagar: A alma separada do corpo representa o ser humano todo? O corpo está excluído da vida pós-mortal? Como se dará a reconstituição da unidade do ser humano na ressurreição? 
Com o intento de responder a estas perguntas, os teólogos medievais oscilam entre tendências platônicas e aristotélicas. Hugo de São Vítor (1096-1141), principal representante da corrente de tendência platônico-agostiniana, em sua visão sobre a constituição antropológica, defende a primazia da alma sobre o corpo, a ponto de identificá-la com o ser humano: "O homem foi feito à imagem e à semelhança de Deus, porque a alma (que é a melhor parte do homem ou que era até mesmo o próprio homem) era imagem e semelhança de Deus" (HUGO DE SÃO VITOR, 1854, p. 264c). Apesar de salvaguardar o primado da alma, Hugo sustenta a tese clássica de que o ser humano é constituído de corpo e alma: "A alma e o corpo são uma só pessoa. Mas não se pode dizer que só a alma ou só a carne é homem" (HUGO DE SÃO VITOR, 1854, p. 405b). Ele afirma, ainda, que a alma, por si mesma, não representa a totalidade do ser humano, que é formado pela alma e pelo corpo (HUGO DE SÃO VITOR, 1854, p. 411a). A alma (espiritual e criada imortal por Deus) e o corpo (carnal e criado mortal por Deus) são distintos. Apesar desta distinção, não se pode afirmar que um princípio se transforme no outro, "ainda que o espírito se rebaixe até o corpo e este se eleve até o espírito" (LADARIA, 2003, p. 111). Entre o corpo e a alma vigora uma relação com um tom acidental e funcional. Hugo de São Vitor, influenciado por Boécio ${ }^{1}$, parece aplicar a definição de pessoa somente à alma, de tal modo que o corpo seria apenas um acréscimo: "A alma, como espírito racional, tem por natureza, por si mesma, o ser pessoal, e quando o corpo se une a ela não se une para constituir uma pessoa, porque ele se une à pessoa" (HUGO DE SÃO VITOR, 1854, p. 409b). Esta identificação da alma com o ser pessoal do homem tem uma motivação escatológica: quando a alma se separa do corpo, no momento da morte, ela continua a ser pessoa, como anteriormente. À alma, como representante do homem todo, está reservado o privilégio da visão beatífica de Deus depois da morte. Assim, a identidade do ser humano é garantida: é o mesmo sujeito antes e depois da morte (RUIZ DE LA PEÑA, 1988, p. 103; LADARIA, 2003, p. 111-112).

A alternativa ao pensamento de Hugo de São Vítor é representada por Gilberto de la Porrée (1070-1154). Segundo Gilberto, em consonância com a tradição, o ser humano não coincide nem com o corpo e nem com a alma, mas com a união dos dois. O ser humano é resultado da "animação do corpo e da incorporação da alma" (RUIZ DE LA PEÑA, 1988, p. 104). Gilberto refuta a definição aristotélica da alma como forma do corpo, porque argumenta que ela seria uma forma acidental, e sustenta que "a alma é verdadeiramente algo subsistente, uma substância” (LADARIA, 2003, p. 110). Para Gilberto, a alma, depois da morte, subsiste em sua condição de separada do corpo, mas não responde pela totalidade do ser humano, ou seja, não é pessoa. A alma descorporalizada significa uma parte e não o

\footnotetext{
${ }^{1}$ Boécio (480-525) definia a pessoa como substância individual de natureza racional.
} 
ser humano todo. Gilberto, seguindo a definição de Boécio, dá um estatuto pessoal à alma separada, mas reconhece que ela não representa a pessoa toda, a qual é una em corpo e alma (LADARIA, 2003, p. 109-110).

A partir do século XII, há um alargamento do influxo da tendência aristotélica, na teologia medieval, que considera o ser humano como uma unidade constituída de um corpo e uma alma. $\mathrm{O}$ influxo aristotélico alcança o seu ponto culminante com Tomás de Aquino (1225-1274) que, seguindo a tradição da primazia da alma sobre o corpo, defende a existência de uma unidade substancial entre ambos princípios ontológicos. Tomás reelabora as teses aristotélicas da relação corpo-alma à luz da tradição bíblico-teológica, conferindo um caráter espiritual à alma ${ }^{2}$. O Angélico insiste na unidade dos princípios ontológicos que constituem o ser humano, de modo que um princípio isolado não corresponde à totalidade humana (TOMÁS DE AQUINO, 2002, I, q. 75, a. 4). A alma é concebida como uma realidade incorpórea, subsistente, espiritual e forma do corpo. Pertence à essência da alma a sua união com o corpo (TOMÁS DE AQUINO, 2002, I, q. 76, a. 1). A alma está ordenada para o corpo. Ela contém em si o corpo, não ao contrário, e faz com ele uma unidade (TOMÁS DE AQUINO, 2002, I, q. 76, a. 3).

A alma é vista como a única forma da matéria prima (TOMÁS DE AQUI$\mathrm{NO}, 2002, \mathrm{I}, \mathrm{q} .76$, a. 4 e 6). É a única forma substancial que concede o ser ao corpo. A alma realiza a sua essência incorporando-se. A informação significa a sua autorealização. O corpo é a matéria informada pela alma. Ele é animado pela alma. O corpo consiste na manifestação da visibilidade e da historicidade da alma que, por sua vez, está interiorizada nele. A "alma é ato do corpo porque pela alma o corpo existe, é organizado e é potência que tem vida" (TOMÁS DE AQUINO, 2002, I, q. 76, a. 4, ad 1). Como o cadáver não é matéria informada pela alma, logo não pode ser visto como corpo. A alma não pré-existe ao corpo nem o corpo pré-existe à alma. O corpo é visto como a condição de possibilidade do vir-a-ser da alma (TOMÁS DE AQUINO, 1952, v. I, 1. II, c. 68). A alma humana comunica o seu ser ao corpo, no qual subsiste. É a alma que abriga o corpo. A unidade humana se funda na alma. O corpo e alma não são vistos como dois princípios completos e independentes que co-existem no mesmo espaço, formando o ser humano, mas os ambos elementos estão substancialmente unidos. Um princípio ontológico, por si mesmo, isolado e desconectado do outro não pode responder pela totalidade do ser humano. Este é uma magnitude constituída pela união substancial dos dois princípios ontológicos.

\footnotetext{
${ }^{2}$ Para Aristóteles, a alma, forma do corpo, era vista como o princípio configurador da realidade material. A matéria sem a "forma" seria reduzida a uma mera possibilidade; a forma se tornaria realidade na unidade com a matéria.
} 
Para o Angélico, a alma não é o homem e nem é pessoa (TOMÁS DE AQUINO, 2002, I, q. 29, a. 1). A alma separada do corpo não corresponde à natureza do ser humano todo e ainda encontra-se numa situação ontologicamente precária. É um estado anômalo e contrário à natureza e à vocação da alma (TOMÁS DE AQUINO, 2002, I, q. 89, a. 1-3; I, q. 118, a. 3). A subsistência da alma desencarnada após a morte, que Tomás afirma em sintonia com a tradição, é uma etapa inconveniente. A alma, por sua natureza, está orientada para a união e não para a separação do corpo. No entanto, contrariamente ao que foi exposto até o momento, Tomás salienta que a situação da alma separada é melhor, porque ela goza de uma maior liberdade para compreender, sem o obstáculo que o corpo representa para a pureza da inteligência (TOMÁS DE AQUINO, 2002, I, q. 89, a. 2, ad 1).

Anteriormente a Tomás de Aquino, o IV concílio de Latrão (1215) já havia afirmado que o ser humano é constituído de corpo e de alma (DENZINGER; HÜNERMANN, 2007, n. 800-801). O concílio de Vienne (1311-1312), provavelmente, sob a influência de Tomás de Aquino, dá um passo além do IV Latrão e declara que os dois princípios ontológicos estão substancialmente unidos: a alma racional é verdadeiramente, por si mesma e essencialmente, forma do corpo humano (DENZINGER; HÜNERMANN, 2007, n. 902). Tratando desta declaração conciliar, Ladaria (2003, p. 128) observa que a "unidade intrínseca do composto humano é garantida diretamente pela alma". No horizonte de Vienne, a relação entre o corpo e a alma não é acidental e nem operacional, mas essencial e substancialmente unitária. O ser humano é uma unidade anímico-corpórea. A declaração de Vienne é completada pelo V concílio de Latrão (1513) o qual afirma que a alma é imortal (DENZINGER; HÜNERMANN, 2007, n. 1440). Esta afirmação trata da singularidade e do destino eterno e pessoal do ser humano. A imortalidade é uma prerrogativa reservada ao ser humano todo e não somente da alma.

\subsection{A relação corpo-alma no Concílio Vaticano II}

A antropologia cristã anterior concebia o ser humano como uma magnitude constituída de corpo e de alma (patrística) de modo que entre estes dois princípios metafísicos vigorava uma união substancial (IV concílio de Latrão, Tomás de Aquino, concílio de Vienne e V concílio de Latrão). O concílio Vaticano II (1962-1965), através da Constituição Pastoral Gaudim et Spes 14 e 15, apresenta uma síntese com uma nova elaboração doutrinal sobre a constituição do ser humano como unidade anímico-corpórea. O concílio, em sintonia com a orientação bíblica da teologia contemporânea, concebe o ser humano como uma realidade concreta, constituída por uma dimensão corporal e uma interioridade. Para a Constituição, as duas dimensões características do ser humano são: a unidade-distinção do corpo e da alma e sua primazia sobre as demais realidades criadas. A Constituição destaca a dignidade do corpo, sua bondade e seu destino último na ressurreição 
final. O ser humano, por sua condição corporal, consiste no compêndio e no climax do mundo material. Por sua condição anímica, o ser humano é superior ao universo material. Ele é a matéria que transcende sua materialidade. A Constituição reafirma as dimensões espiritual e imortal da alma. O ser humano é uno em corpo (referência ao mundo e condição horizontal) e alma (referência a Deus e condição vertical).

\section{$2 \mathrm{O}$ ser humano é uno em corpo e alma: uma aproximação contemporânea}

A antropologia cristã concebe o ser humano como uma unidade na pluralidade de suas dimensões. O ser humano, enquanto corpo e alma, é uma uni-pluralidade. A antropologia cristã não compactua com o dualismo antropológico porque o ser humano não é um espaço no qual o corpo e a alma coabitam sem nenhum tipo de vínculo; corpo e alma não são duas instâncias autônomas e independentes que coexistem juntas, como preconiza o dualismo antropológico. Por outro lado, a antropologia cristã, também, não comunga com o monismo antropológico, pois defende que o ser humano não pode ser reduzido a um princípio material ou espiritual. Para a antropologia cristã, o ser humano é carne animada e alma encarnada.

A unidade anímico-corpórea que constitui o ser humano é uma expressão da "experiência originária que o eu tem de si mesmo" (RUIZ DE LA PEÑA, 1988, p. 129). O ser humano se autopercebe como um eu concreto, encarnado, singular, histórico e não como uma subjetividade desconectada da realidade, espiritualista ou fictícia. Não é como defende o dualismo antropológico cartesiano, fundamentado na formulação res cogitans-res extensa, que reduz o ser humano a uma consciência pensante (cogito, ergo sum). O ser humano não é produto de uma equação antropológica: corpo mais alma. Também não é fruto do ajustamento destas duas partes. A unidade múltipla do ser humano não é formada por duas camadas que se acomodam, nem por duas engrenagens que se encaixam e nem por dois estratos que se justapõem. Reagindo a esta visão dualista, o teólogo protestante K. Barth (1961, p. 73), defende um "monismo concreto" que não considera o corpo e nem a alma "como duas partes, mas como dois fatores da natureza humana, una e indivisível". O ser humano é uma unidade corpóreo-espiritual, psicofísica e psicoorgânica. Na unidade antropológica, não há uma supremacia, primado ou domínio de um co-princípio metafísico sobre o outro. Partindo do princípio da unidade antropológica, não há um ato que seja exclusivamente espiritual ou corporal. O que há é uma ação única da unidade antropológica, que constitui o ser humano, em cada circunstância. A unidade corpóreo-anímica está toda presente em toda atividade humana. 
O ser humano não "tem", mas "é" uma unidade corpóreo-animada (RUIZ DE LA PEÑA, 1988, 129; LADARIA, 1998, p. 69; RUBIO, 2001, p. 283). Esta unidade faz parte da constituição humana e não é uma propriedade que o ser humano manipula ou uma "estrutura selada por um decreto arbitrário entre dois termos exteriores" (MERLEAU-PONTY, 1945, p. 112). O ser humano não é formado por uma unidade que se confunde e nem por uma distinção que se separa. Cada princípio metafísico, que constitui o ser humano, não se identifica e nem se diferencia radicalmente do outro. Em outros termos, não há uma homogeinização e nem uma heterogeinização dos princípios que compõem o ser humano. Assim, os princípios (corpo e alma ou espírito e matéria) que constituem o ser humano formam uma unidade não-monista e uma dualidade não-dualista. O ser humano é uma unidade dual e uma dualidade una, isto é, um ente constituído por princípios distintos que formam um todo único. A "unidade no ser humano não anula a dualidade (espiritualidade-corporeidade) e vice-versa" (RUBIO, 2001, p. 349). O ser humano é uma totalidade e uma unicidade ontológica em que os princípios estruturantes são distintos, porém não separáveis.

A alma não é um espírito puro, nem uma realidade espiritual pré-existente ao corpo, nem é fruto de uma emanação divina, nem um "fragmento" (RAHNER, 2002, p. 290) do ser humano todo, nem sua estrutura superior e nem o seu pavimento mais nobre, mas o princípio que vitaliza, interioriza e anima o corpo. A alma é um co-princípio metafísico, cuja vocação e razão de ser está em sua encarnação e corporificação. A alma não é a parte invisível da composição humana, como se fosse um espírito oculto e aprisionado no corpo, mas ela se expressa e existe no ser do corpo. Só tem sentido falar da alma enquanto um princípio encarnado no corpo. Através da alma, o corpo se torna um organismo vivo, se expressa e se constitui. O corpo, pelo influxo vibrante da alma, é uma realidade dinâmica, comunicativa e movente. A alma é a interioridade e a subjetividade do corpo. Um corpo des-animado é um cadáver, uma matéria sem vida, sem expressão, imóvel e incomunicável. Mas, um corpo almificado é uma matéria animada e vitalizada. A alma é inconcebível fora da corporalidade, na qual "opera sua expressão e autorealização" (RUIZ DE LA PEÑA, 1988, p. 131). O corpo não é um instrumento e nem um fantoche nas mãos da alma, mas o seu modo de ser. A alma não é um princípio ativo que governa um corpo inerte. $\mathrm{O}$ ser humano não é constituído por uma alma inteligente e um corpo ignorante. Não há um primado da alma sobre o corpo e nem vice-versa. O primado está na igualdade qualitativa e na comunhão recíproca que há entre ambos os princípios.

Não existe corpo sem alma e nem alma sem corpo. Se a alma pudesse existir separada do corpo, num suposto estado desencarnado, estaria contrariando a sua vocação para a comunhão com o corpo. Caso este estado fosse possível, a alma estaria numa condição ontológica precária e anômala. Se um suposto estado descorporalizado da alma, semelhante a uma condição 
angélica, liberto da relação informante com o corpo, fosse sinônimo de uma pobreza espiritual seria, também, uma traição à vocação informante da alma. A alma é um ser-para e ser-com o corpo. A encarnação da alma não é uma fase transitória para se alcançar um estado desmaterializado, mas trata-se de sua genuína índole. Referir-se à alma é referir-se ao seu estado encarnado. Dizer alma é afirmar o corpo e vice-versa. A alma não se autorealiza à margem da matéria e nem a matéria se autorealiza ou se autodetermina independentemente da alma. A alma humana encontra a sua realização na relação com o corpo de modo que ela não se torna mais espiritual na proporção em que se separa do corpo, mas na medida em que se corporifica.

Nenhum princípio ontológico, que compõe o ser humano (corpo ou alma), se realiza sozinho ou à margem do outro. Um princípio se realiza pela relação com o outro. O corpo não é um fragmento da matéria que ocupa lugar no espaço e nem é uma realidade inimiga de Deus, mas "alteridade", "símbolo", "expressão" e manifestação fenomênica da alma (RAHNER, 2002, p. 288-289), que, por sua vez, está dotada de interioridade, densidade e profundidade. O corpo interioriza, visibiliza, comunica e auto-elabora os atributos da alma. A alma se expressa de forma histórica e espaço-temporal no corpo, o qual não se restringe à superficialidade epidérmica, mas possui uma interioridade anímica. O ser humano inteiro é corpo e alma, não de forma contígua, mas no sentido de ser constituído por dois princípios diversos que estão reciprocamente ordenados, condicionados e orientados, formando uma unidade antropológica. Segundo o teólogo protestante Moltmann (1993, p. 367), “a unidade de alma e corpo, de interior e exterior, de centro e periferia da pessoa deve ser compreendida nas formas de aliança, comunhão, atuação recíproca, contexto mútuo, harmonia e amizade". Entre o corpo e alma não vigora uma relação hierárquica ou piramidal, mas de conformação pericorética. Para Flick-Alszeghy (1999, p. 152), a unidade e a dualidade dos aspectos que compõem o ser humano se expressa de modo mais preciso pela categoria "sujeito encarnado".

A antropologia cristã não rechaça e nem censura, previamente, a alma e nem a matéria, mas busca unificá-las em uma síntese coerente. A antropologia cristã não é espiritualista e nem materialista, mas é uma unidade que integra ambos os aspectos. Os dois princípios estruturais da constituição humana não se identificam e nem se misturam, mas estão co-relacionados de forma que a essência de um se dá na relação com o outro. A identidade de um princípio metafísico se constrói mediante a relação com a alteridade do outro princípio. $\mathrm{O}$ corpo não é a alma e vice-versa. $\mathrm{O}$ interior e o exterior são distintos, mas não indiferentes ou adversários. Mas o que o corpo "é" ele o é em relação à alma e vice-versa. A distinção entre os princípios do binômio antropológico se situa no plano meta-existencial, ou seja, metafísico. O ser humano não é só corpo e nem só alma, ou seja, cada dimensão, separadamente, não o constitui e nem responde pela totalidade 
do seu ser. É através da unidade e da aliança de ambos os princípios que o ser humano acontece, torna-se e vem a ser.

O filósofo espanhol X. Zubiri compreende a relação corpo-alma de um modo distinto e com uma nova linguagem. Segundo Zubiri, o ser humano é uma unidade sistemática constituída por subsistemas parciais: a psique e o organismo. Na visão do filósofo, a psique, que na linguagem clássica corresponde à alma, emerge, de forma processual, do próprio organismo, o qual é formado por células germinais, que linguagem na clássica é o corpo (ZUBIRI, 1986, p. 464). Assim, a psique é originária do subsistema organismo. Entre o organismo e a psique há uma determinação recíproca: "Sua psique é formal e constitutivamente psique de um organismo, e este é formal e constitutivamente organismo de uma psique. Esta é desde si mesma orgânica e o organismo é desde si mesmo psíquico" (ZUBIRI, 1986, p. 49). Ambos subsistemas se constituem, se ordenam, "se co-determinam como realidades em ato e ex aequo" para formar a unidade sistemática psicoorgânica, que é o ser humano (ZUBIRI, 1986, p. 49). Os subsistemas, organismo e psique, são irredutíveis e distintos um do outro, não obstante estejam em mútua complementariedade e co-determinação.

A constituição e a relação existente entre os princípios material e espiritual, objeto de reflexão da antropologia cristã, também, está presente nas antropologias materialistas contemporâneas, mas um novo verniz através da relação mente-cérebro. Estas novas antropologias, com um olhar fisicista para o ser humano, colocam questões desafiadoras para a antropologia cristã.

\section{$3 \mathrm{Da}$ relação corpo-alma à mente-cérebro: as novas antropologias}

Algumas das novas antropologias do século XX (teoria da identidade, emergentismo, dualismo interacionista e cibernéticos) reapresentam a histórica relação entre o corpo e a alma, mas com uma nova linguagem e com um novo rótulo: a relação mente-cérebro. Registra-se a passagem de uma linguagem filosófico-teológica para uma linguagem de cunho mais científico (CANOBBIO, 2012, p. 17-18).

Quem é o ser humano? Ele é constituído por quais princípios ontológicos? Ele possui uma diversidade de princípios ontológicos ou pode ser reduzido a um único princípio? $\mathrm{O}$ ser humano pode ser homologado a um animal, a uma realidade físico-química ou a uma máquina? Ele se distingue onto-axiologicamente das demais realidades finitas? Estas e outras interpelações estão presentes, atualmente, nos interdisciplinares debates antropológicos que contam com a adesão de filósofos, psicólogos, teólogos, biólogos, etólogos, neurólogos, cibernéticos e outros. A discussão 
atual gravita em torno que questões como: A mente existe? Ela é distinta ou igual ao cérebro? $\mathrm{O}$ cérebro pode ser comparado a uma máquina de carne? Quem é o sujeito de atos mentais como pensar, recordar e desejar (a mente ou o cérebro)? Em outros termos: "basta esta estrutura orgânica prodigiosamente sofisticada, que é o cérebro, para explicar a conduta, as faculdades e propriedades do ser humano? Ou é preciso postular um outro fator explicativo do fenômeno homem, não orgânico, não material?" (RUIZ DE LA PEÑA, 1987, p. 211). Quanto à existência da mente, tem-se praticamente uma concordância geral no discurso interdisciplinar atual. As divergências surgem quando se trata de precisar que tipo de relação há entre a mente e o cérebro: alguns defendem que há uma identificação e outros patrocinam uma distinção entre ambos.

\subsection{Teoria da identidade psiconeural: a mente é o cérebro}

A teoria da identidade psiconeural ${ }^{3}$, que advoga a identificação entre a mente e o cérebro, foi criada pelo filósofo austríaco, naturalizado estadunidense, Herbert Fiegl (1902-1988) e exposta em sua obra The "Mental" and the "Physical" (1967, segunda edição). A teoria de Fiegl consta de três etapas: a) a mente e os estados mentais são realidades objetivas; b) a mente é o cérebro; c) o cérebro, como entidade biológica, é uma estrutura física.

Na visão de Fiegl, os estados, os processos e os eventos mentais (desejos, projetos, afetos, deliberação, dor etc.) são fatores que causam o comportamento humano. Estes estados mentais têm uma existência objetiva, uma consistência própria e são anteriores à conduta humana, que é fruto destes estados. A mente, assim como o cérebro, é uma realidade objetiva e o princípio interno causador do comportamento humano. Logo, o ser humano é concebido como um eu consciente (o detentor de uma unidade consciente que centraliza, coordena e organiza os dados da experiência), possuidor de uma estrutura central de personalidade que funciona como um elo na cadeia causal de sua conduta (RUIZ DE LA PEÑA, 1983, p. 109-110).

Uma vez detectado o caráter real e objetivo da mente segue-se a sua identificação com o cérebro. Há uma homologação psiconeural: a mente existe e é o cérebro (mente = cérebro). A mente não pode ser compreendida recorrendo a um fator não-orgânico, não-somático e não-material, mas a algum orgão da estrutura biológica humana (o cérebro) que seja suficiente para explicar todos os processos mentais, condutas e propriedades do ser humano. Desta forma, o cérebro é o orgão ao qual se atribui a responsabilidade pelas propriedades, estados e comportamentos mentais do ser humano. O cérebro é o agente causador destes processos mentais, ou seja,

${ }^{3}$ A exposição desta teoria está baseada na leitura e em diálogo com o teólogo espanhol J.L. RUIZ DE LA PEÑA, 1988, p. 116-118; 1983, p. 109-122. 
de todas as ações humanas. Na ótica de Feigl, o binômio mente-cérebro é o responsável pela atividade humana. Neste contexto, é preciso indagar: a neurologia está em condições de responsabilizar o cérebro por tudo aquilo que o ser humano é capaz de fazer? (RUIZ DE LA PEÑA, 1988, p. 116-117).

A resposta de Feigl a esta pergunta é afirmativa. Os processos teleológicos da mente, como a intencionalidade do comportamento, o conhecimento, a vontade, a decisão, a liberdade e outros, são fenômenos que a psicofisiologia atual pode atribuir uma causa neurológica. Em outros termos, o comportamento humano tem uma explicação e um fundamento fisiológico. Assim, por exemplo, as ações da vontade e da liberdade são atividades que podem ser explicadas como resultantes de processos e de estados mentais (cerebrais) que atuam no organismo humano. Deste modo, as ações livres, assim como quaisquer outras atividades humanas, seriam previsíveis, caso seja realmente possível compreender o mecanismo do cérebro que as causa. Considerando que seja possível compreender, previamente, o funcionamento do cérebro, assim haveria a possibilidade de antever o comportamento humano. Destarte, o ser humano seria um ser previsível, programado e suas atividades poderiam ser conhecidas antecipadamente. As ações do ser humano seriam uma consequência direta das ações de seus idênticos processos neurônicos. Este postulado patrocina uma identificação da subjetividade com a objetividade. $\mathrm{O}$ que pertence ao mundo da subjetividade, da particularidade e da privacidade poderia ser compreendido objetiva, publica e cientificamente. Há uma redução do psicológico ao fisiológico, do objetivo ao subjetivo (psíquico = físico) (RUIZ DE LA PEÑA, 1983, p. 111-112).

A visão ontológica sobre a qual está edificada a teoria da identidade é materialista e fisicista. Feigl promove uma homologação da mente ao cérebro, do psíquico ao biológico e do biológico ao físico. Para o monismo materialista da teoria da identidade, a matéria é a única realidade presente em tudo aquilo que existe: o real é o material. A realidade é uma homogeneidade material, detentora de uma textura ontológica única: a matéria. As leis que explicam o funcionamento do universo são exclusivamente físicas. São as leis físicas que explicam o funcionamento dos mecanismos biológicos, químicos e psíquicos. A teoria da identidade defende uma homogeneidade material e física da realidade. Assim, entre as realidades existentes no universo (homem, animal, máquina etc.) não há um desnível onto-axiológico, qualitativo e humanista. Destarte, todas as realidades gozam do mesmo status ontológico. A realidade é concebida a partir da ótica de um monismo físico e material.

Fiegl reconhece dois pontos frágeis em sua teoria: a natureza da memória e a dimensão ética. Para estes eventos mentais, a neurologia não disporia de uma explicação plausível. Espera-se que, futuramente, a psicofisiologia possa oferecer uma explicação sustentável para estes pontos obscuros, 
caso contrário a teoria deverá ser desconsiderada porque a sua validade depende de uma averiguação empírica, própria das ciências experimentais. Presume-se que a neurologia e a física do futuro apresentem evidências empíricas que ofereçam sustentação à tese propositiva da teoria da identidade. Ou seja, a teoria da identidade depende de demonstrações futuras (RUIZ DE LA PEÑA, 1983, p. 113).

Feigl defende um monismo materialista e fisicista: há uma unicidade de substância e não de propriedades. A realidade é reduzida e regida pela física. O real só pode ser compreendido pelas leis da física. Não há uma variedade qualitativa presente na realidade material. Há uma homogeneidade entre a mente e a estrutura físico-biológica do cérebro. A mente não é uma magnitude emergente do cérebro, mas identificada com ele. A mente e o cérebro constituem uma única realidade.

Fazendo uma avaliação aproximativa da teoria da identidade, é possível observar que a homogeneização do real, ou seja, a redução do real a um único denominador comum, não atesta o que a experiência e a sensibilidade humanas captam. A experiência demonstra que a realidade não é idêntica, mas diversa, heterogênea e plural. A teoria da identidade está na contra-mão de uma visão evolutiva para a qual do processo evolutivo emergem novas realidades. Na visão de tal teoria, não haveria uma distinção no real, mas apenas configurações diversas de um mesmo processo. A realidade seria marcada pela mesmidade e não pela novidade. Desta forma, seria incompatível aderir à teoria da identidade e, ao mesmo tempo, defender o darwinismo. O monismo fisicista da teoria da identidade apresenta uma visão da realidade em que toda novidade e criatividade estão excluídas (RUIZ DE LA PEÑA, 1989, p. 229-231).

As teorias de Fiegl e do cibernético L. Ruiz de Gopegui, como se verificará em seguida, necessitam de um embasamento empírico através da neurologia. No entanto, alguns neurólogos (Eccles, Penfield e Sperry) e filósofos contemporâneos (Karl Popper e Xavier Zubiri) expressam uma rejeição diante da identificação mente-cérebro. Logo, do ponto de vista neurológico, a antropologia da identidade psiconeural está destituída de uma fundamentação empírica. A redução do psíquico ao biológico, preconizada pela teoria da identidade, será refutada pelo filósofo M. Bunge, como verá em seguida. É possível comprovar que as funções cerebrais humanas podem ser explicadas biologicamente? A redução do biológico ao físico do cérebro humano, defendida pela teoria da identidade, é rejeitada por estudiosos da filosofia da biologia.

\footnotetext{
${ }^{4}$ A teoria da identidade psiconeural de Feigl, também, é defendida pelo filósofo australiano David Malet Armstrong (1926-), em sua obra A Materialist Theory of the Mind (1968).
} 


\subsection{Emergentismo: a mente é uma qualidade emergente do cérebro}

A teoria materialista emergentista defendida, dentre outros, pelo filósofo argentino Mario Bunge (1919-), postula, em sintonia com o materialismo fisicista de Fiegl, uma identificação do binômio mente-cérebro. Para as duas correntes, os estados ou os processos mentais (sentir, recordar, imaginar, desejar, pensar e outros) são estados do sistema nervoso central (ou de uma parte dele). Ambas as correntes procuram compreender o mental através do estudo dos componentes cerebrais e suas interações: "ou seja, ambas são reducionistas ainda que de tipos diferentes" (BUNGE, 2011, p. 24). Os estados mentais não subsistem por si mesmos, mas estão ligados aos processos ou aos estados de alguma entidade. Isto significa afirmar que a mente não é uma magnitude independente, mas está vinculada ao cérebro. Portanto, o materialismo fisicista e o emergentista sustentam que a atividade mental não prescinde da atividade cerebral.

A diferença que há entre ambos reside na forma de conceber a natureza do sistema nervoso central e no modo de explicar as funções mentais como processos do sistema nervoso central (BUNGE, 2011, p. 27-28). O materialismo fisicista salienta que o sistema nervoso central é uma entidade física que se diferencia de outros sistemas físicos por sua complexidade. Assim, o mental deve ser compreendido como uma realidade regida por leis físicas. Para esta corrente materialista, a psicologia seria um departamento da física e o cérebro seria uma espécie de computador. Já, contrariamente, o materialismo emergentista afirma que "o sistema nervoso central não é uma entidade física, mas um biosistema, ou seja, uma coisa complexa dotada de propriedades e leis particulares dos seres vivos, algumas delas muito peculiares" como, por exemplo, a atividade espontânea ou autoprovocada por parte das células nervosas (BUNGE, 2011, p. 28). Isto significa que o cérebro é um biosistema que supõe, mas não se reduz ao nível do físico-químico e do biológico. Na visão do materialismo emergentista, a emergência do mental consiste em afirmar que as propriedades de um sistema nervoso central são propriedades sistêmicas que teriam surgido no curso do processo evolutivo biológico (BUNGE, 2011, p. 28). O materialismo emergentista se distancia do materialismo fisicista porque preconiza uma descontinuidade entre o biológico e o mental. A mente ostentaria propriedades e faculdades que transcendem o dado puramente biológico, fisiológico e físico.

Na ótica do materialismo emergentista, a matéria é a única substância; o real é material e vice-versa. Porém, a matéria se compõe de níveis qualitativamente distintos de ser (estratos diversos do real) de modo que cada um destes níveis supõe e transcende o seu anterior. O nível posterior considera e simultaneamente supera o anterior. Há uma superação ontológica e uma irredutibilidade de um nível em relação ao outro. Há um monismo substancial (a matéria é a substância basilar da realidade) e um pluralis- 
mo de propriedades (as leis e as capacidades funcionais são diversas). A realidade é "ontologicamente pluralista em relação às propriedades e às leis" (BUNGE, 2011, p. 28). Ela é dinâmica, evolutiva e geradora de novidade. O emergentismo justifica o poliformismo e a evolução. A matéria, única substância constituinte da realidade, é dotada de uma variedade de propriedades e de uma diversidade de níveis de ser. No mundo material há uma hierarquia ontológica e qualitativa de modo que o ser humano ocupa a cúpula (BUNGE, 2011, p. 109-111).

O emergentismo argumenta que a realidade é permeada por uma diversidade, uma criatividade e uma pluralidade de formas. O real é materialmente plural e diverso. Há uma distinção qualitativa entre os entes materiais que compõem o universo. Contrariamente à homogeneidade ontológica do monismo materialista-fisicista, o emergentismo constata a existência de processos evolutivos na realidade através do "surgimento de coisas absolutamente novas, ou seja, entes que possuem propriedades que não existiam antes" (BUNGE, 2011, p. 44). Os processos evolutivos geram tipos ou níveis de entes diversos. O emergentismo justifica a existência do poliformismo e da evolução. Ele está em sintonia com "a psicologia evolutiva e a neurofisiologia, que mostram a maturação gradual do cérebro e da conduta", e também com a biologia evolutiva que demonstra, observando "o desenvolvimento gradual da conduta e das capacidades mentais em diversas espécies", que a mente não é uma magnitude exclusiva do ser humano (BUNGE, 2011, p. 45).

A homogeneidade ontológica do materialismo fisicista, rejeitando esta visão evolutiva que conduz à pluralidade qualitativa dos entes, concebe a realidade como idêntica, nivelada, estática e sem um desnível qualitativo entre os entes. “O materialismo reducionista - ou fisicismo - é insustentável porque não consegue dar conta dos traços específicos que o mental possui. Em particular não nos permite distinguir o homem de seu primo mais próximo, o chipanzé, muito parecido com o homem do ponto de vista celular e muito diferente em níveis superiores" (BUNGE, 2011, p. 31). Já o emergentismo postula que há uma heterogeneidade, dinamicidade, distinção e ascensão ontológica na realidade. No cume da pirâmide ontológica se encontram os psicossistemas e os sociossistemas (o ser humano), cuja condição de possibilidade são os sistemas inferiores (biológicos, químicos e físicos).

Bunge aplica o materialismo emergentista à relação mente-cérebro. $\mathrm{O}$ argentino refuta o reducionismo ontológico e epistemológico do materialismo fisicista defendido, por exemplo, pela teoria da identidade psiconeural, porque ele não compactua com a percepção de uma variedade qualitativa da realidade (BUNGE, 2011, p. 28). Segundo Bunge (2011, p. 24), a mente é o cérebro, porém "o cérebro se difere qualitativamente de qualquer outro sistema material, particularmente dos computadores". Deste modo, o ser 
humano, por sua qualidade cerebral, se difere de uma máquina e de um computador. Há uma disparidade qualitativa entre o cérebro humano e as outras realidades físicas. O cérebro humano ostenta uma qualidade emergente, em relação aos demais entes da biosfera. Em virtude disto, o ser humano se distingue qualitativamente de qualquer outra magnitude física, química ou biológica.

“Os eventos mentais são indubitavelmente emergentes em relação aos eventos biológicos que não são mentais (tais como a divisão celular)" (BUNGE, 2011, p. 36-37). Em razão desta constatação de Bunge, a equação mente = cérebro necessita de um reparo: "todos os estados mentais são estados cerebrais, mas não vice-versa, ou seja, os estados mentais constituem um subconjunto do conjunto dos estados cerebrais" (BUNGE, 2011, p. 54). Todo processo metal é um processo cerebral. A atividade cerebral específica de certos sistemas neuronais é a atividade mental. Os sistemas neuronais possuem propriedades intransferíveis como o caráter espontâneo de sua atividade, plasticidade e criatividade. A plasticidade, ou seja, a capacidade de autoprogramação e de autoorganização, devido à variável conectividade intercelular, é a propriedade emergente mais importante do sistema cerebral (BUNGE, 2011, p. 68-77). O traço emergente do humano é o sistema neuronal plástico ("psicón"). É da plasticidade que derivam as qualidades irredutíveis do cérebro humano, ou seja, o que se denomina como "mente". Mas o que é propriamente a mente? Segundo Bunge (2011, p. 53), "não existe uma mente independentemente do cérebro, nem paralela a ele, ou em interação com ele. A mente é uma coleção de funções [um conjunto de atividades] de um sistema nervoso central extremamente complexo" (contra o dualismo psicofísico). Ela "é uma propriedade emergente que só possuem os animais dotados de um sistema nervoso extremamente complexo e plástico" (contra o materialismo fisicista) (BUNGE, 2011, p. 229). A mente não é uma realidade imaterial ou espiritual e nem uma magnitude separada do cérebro ou supraorgânica, mas a sua realidade emergente. Não há mente sem cérebro e nem sem corpo, mas o que existe é o cérebro possuidor da mente, ou seja, animais mentalistas. Em outros termos, "o mental é emergente em relação ao meramente físico" (BUNGE, 2011, p. 230). O mental é a realidade material que, hipoteticamente, diverge do resto da matéria.

Bunge reconhece que a proposta reflexiva do emergentismo materialista "ainda é imatura" e não consiste numa "teoria propriamente", mas trata-se de uma "hipótese programática" que busca ser incluída em outras teorias científicas (BUNGE, 2011, p. 43). A hipótese bungeana apresenta-se como uma reflexão científica da mente e um enfoque biológico do estudo do espírito (BUNGE, 2011, p. 26). Para o argentino, o emergentismo materialista é uma maior proximidade com o enfoque científico do que o materialismo fisicista ou dualismo psicofísico. 
“O emergentismo materialista reconhece uma característica emergente do mental e sugere que devemos estudá-la, contando com a contribuição de outras ciências [neurologia, psicofisiologia etc.], porque o cérebro é um sistema com múltiplos níveis" (BUNGE, 2011, p. 45). O emergentismo postula que "os fatos mentais não são afeições de uma substância imaterial, mas que são estados, sucessos ou processos que se apresentam em organismos naturais, ou seja, é compatível com as ciências naturais e, portanto, podemos utilizar os procedimentos habituais da ciência para investigar os fatos mentais, o qual transforma a psicologia numa ciência natural, deixando de ser sobrenatural" (BUNGE, 2011, p. 43). A psicologia é vista em relação com as outras ciências, em particular, com a neurociência. O emergentismo é um "programa prometedor e não um dispositivo para desanimar a investigação" (BUNGE, 2011, p. 231). Na verdade, a hipótese de Bunge se situa no mesmo plano do realismo prometedor que caracterizava as propostas de Fiegl.

Contrariamente à perspectiva anti-humanista de Fiegl, o materialismo emergentista de Bunge tem uma visão humanista da realidade: o ser humano ocupa um primado ontológico (por causa de sua criatividade, originalidade, autoconsciência, linguagem, sociabilidade, liberdade, moral etc.), em relação aos demais seres. O ser humano é "o único animal absolutamente criativo, o único capaz de criar a ciência do mental e de dar forma à sua própria vida, à luz de seu conhecimento e de suas preocupações" (BUNGE, 2011, p. 232). Ele se difere substancialmente do seu entorno, em relação ao qual é irredutível e ontologicamente superior.

A teoria emergentista de Bunge tem alguns aspectos discutíveis. Não seria paradoxal afirmar a existência de um pluralismo de propriedades diversas e irredutíveis e simultaneamente sustentar um monismo substancial? O emergentismo não tem um teor mais pluralista do que monista? Para o emergentismo, a pluralidade e a novidade dos seres emergem do monismo substancial da realidade. Faz sentido considerar como material o que hipoteticamente destoa, do ponto de vista qualitativo, da realidade? $\mathrm{O}$ emergentismo não seria um materialismo camuflado de dualismo? Se a mente ostenta uma qualidade emergente, destoante de toda a realidade material, não seria plausível atribuir-lhe uma índole não-física, não-química, não-biológica e não-material? Como considerar material o que diverge qualitativamente da matéria? Não seria mais lógico, no plano terminológico, designar aquilo que possui uma qualidade emergente da matéria como um termo distinto? Para Bunge, a mente está relacionada e é originária da matéria, mas se distingue dela.

O emergentismo defende que o processo evolutivo propiciaria o surgimento do novo e do distinto. A emergência seria fruto da novidade em que o processo se desembocaria. Na verdade, esta novidade emergente é apenas uma manifestação, um desdobramento e uma epifania de algo já presente 
ou pré-contido, porém não expresso, na realidade. A novidade emergente não é marcada por um conteúdo novo, mas uma nova manifestação do real.

O monismo materialista e fisicista da teoria da identidade psiconeural é coerente e compacto. Já o emergentismo tem somente o rótulo de monismo porque no subterrâneo de sua tese se oculta um pluralismo. Uma forma de salvar o emergentismo seria afirmar que o material se autotranscende em direção ao genuinamente distinto de si e do ontologicamente novo. É possível admitir que o autotranscendimento da matéria possa levar ao surgimento de uma realidade distinta e não-material? A matéria está num processo ascensional de autosuperação, se autotranscendendo em direção ao qualitativamente superior. A tese segundo a qual o material está se autotranscendendo em direção ao novo, ao diverso, ao ontologicamente mais rico e superior não seria compatível com o conceito teológico de alma? Seria possível conceber, teologicamente, a alma como a conclusão do processo de autotranscendimento da matéria? Certamente, o conceito de alma é inegável para uma antropologia humanista, como a de Bunge, que admite a diferença qualitativa e entitativa entre o ser humano e o seu entorno. A noção de "alma", como expressão da singularidade e da onto-axiologia do ser humano, é incompatível com os materialismos que reduzem o ser humano ao nível do biológico, do físico, do animal e do cibernético (RUIZ DE LA PEÑA, 1983, p. 168).

\subsection{O dualismo interacionista: a diversidade da relação mente- cérebro}

O dualismo interacionista é a expressão de uma rejeição das teorias materialistas da mente. Os principais representantes do interacionismo estão no campo filosófico (K. Popper) e neurológico (W. Penfield e J.C. Eccles). Não obstante exista uma disparidade nos pontos de partida, filósofos e neurólogos chegam a pontos comuns: “a mente não é o cérebro; o cérebro não é suficiente para explicar os fenômenos mentais; existe no homem, além da estrutura cerebral, outra realidade de natureza distinta, não-orgânica, não-material, à qual se deve o caráter único do humano" (RUIZ DE LA PEÑA, 1983, p. 137).

Segundo Popper (1902-1994), a existência dos estados físicos e mentais e a relação entre eles é uma questão tratada pelo problema corpo-mente ou pelo problema físico-psíquico. $\mathrm{O}$ interacionismo se apresenta como uma solução para este problema, defendendo que entre o físico e o mental há uma interação. "Isso leva, mais precisamente, a uma descrição do problema corpo-mente como problema cérebro-mente, já que a interação é arguida como sendo localizada no cérebro" (POPPER; ECCLES, 1991, p. 60).

Na visão de Popper, a relação entre a mente e o cérebro pode se tornar mais clara a partir da introdução de uma divisão tripartite (teoria dos 
três mundos). Segundo Popper, o mundo 1 é composto pelas "entidades do mundo físico - processos, forças, campos de forças - que interagem entre si e, portanto, com corpos materiais. Assim, conjecturamos que eles são reais, mesmo que esta realidade permaneça conjectural" (POPPER; ECCLES, 1991, p. 59). Portanto, o mundo 1 se refere ao mundo físico. Além do mundo físico, há o mundo dos fenômenos mentais: "eu suponho que existam os estados mentais, e que eles são reais, já que interagem com nosso corpo" (POPPER; ECCLES, 1991, p. 59). O mundo destes estados mentais é o mundo 2, que se refere aos estados de consciência, às disposições psicológicas, às experiências subjetivas e aos estados inconscientes. O mundo 2 trata, de forma explícita, da relação mente-cérebro (ou mente-corpo). Por fim, o mundo 3 é formado pelo "conteúdo do pensamento, isto é, pelos produtos da mente humana" (POPPER; ECCLES, 1991, p. 62). Este mundo é constituído por "estórias, mitos explicativos, artefatos, teorias científicas (verdadeiras ou falsas), os problemas científicos, as instituições sociais e as obras de arte. Os objetos do mundo 3 são da nossa própria autoria" (POPPER; ECCLES, 1991, p. 62).

Muitos objetos do mundo 3 existem sob a forma de objetos materiais (mundo 1). Assim, são objetos que pertencem tanto ao mundo 1 quanto ao mundo 3 como, por exemplo, uma escultura, um livro, uma teoria científica. Certos objetos (um livro, uma pintura), primeiramente, existem na mente de quem os cria e depois se tornam objetos materiais. Para Popper, "os objetos do mundo 3 podem ser reais [...] não só nas suas materializações ou corporificações no mundo 1, mas também nos seus aspectos, no mundo 3" (POPPER; ECCLES, 1991, p. 62). Em outros termos, os objetos do mundo 3 são reais independentemente de sua existência material (mundo 1). Um exemplo iluminador desta tese é uma teoria científica: "sua discussão crítica, sua comprovação experimental e sua aplicação, que pode mudar a face da terra, e assim do mundo 1" (POPPER; ECCLES, 1991, p. 63). Os produtos da mente (mundo 3) podem transformar a realidade física (mundo 1). No entanto, uma teoria científica não conduz necessariamente à fabricação de um objeto do mundo 1. Deste modo, pode-se dizer que há objetos reais que não são corpóreos como, por exemplo, o mundo dos números. Isto significa que os produtos da mente (as teorias científicas, por exemplo), uma vez extraídos dela, conquistam uma certa autonomia e independência em relação à própria mente. "Pode-se dizer que o mundo 3 é feito pelo homem somente na sua origem, e que uma vez existindo teorias, elas começam a ter vida própria: elas produzem consequências previamente invisíveis, e também novos problemas" (POPPER; ECCLES, 1991, p. 64). O mundo 3 é permeado por uma objetividade e autonomia.

Há uma interrelação entre os três mundos: "os objetos do mundo 3 [...] podem agir sobre o mundo 2; isto quer dizer sobre nossa mente, sobre nós. Por outro lado, podemos agir sobre o mundo 1" (POPPER; ECCLES, 1991, p. 71). Na verdade, o mundo 3 supõe a existência do mundo 2: os 
processos mentais requerem a existência de uma instância consciente e subjetiva. A interação entre o mundo 3 e o mundo 1 se dá pela mediação dos processos mentais do mundo 2. Sem o mundo 2 não seria possível uma interação entre os mundos 3 e 1 . O caráter real dos objetos do mundo 3 é, por consequência, a afirmação do realismo do mundo 2 (POPPER; ECCLES, 1991, p. 72-73). Entre os três mundos, há uma recíproca interação: o mundo 1 age sobre os mundos 2 e 3 e estes dois últimos agem sobre aquele.

Popper, influenciado pelo evolucionismo darwinista, acredita que é possível emergir do universo material uma nova realidade. A "matéria morta", depois de passar por várias etapas evolutivas, produziu "mentes e, por fim, o cérebro e a mente humanos, a consciência humana do 'eu' [...] A matéria transcende a si própria, produzindo a mente, a vontade e todo um mundo de produtos da mente humana. Um dos primeiros produtos da mente humana é a linguagem humana [...] o cérebro e a mente evoluíram em interação com a linguagem" (POPPER; ECCLES, 1991, p. 28-29). A mente é um produto da evolução e da auto-organização da matéria. É uma entidade que transcende a realidade puramente material, física e corporal, apesar da realidade física ser o pressuposto de sua existência. A identidade e a integridade do eu possuem um suporte físico, o cérebro. A existência do mental não prescinde do físico, mas é causado a partir da configuração evolutiva da realidade física. A mente representa o salto qualitativo da matéria. É uma magnitude emergente presente na matéria, um produto emergente do cérebro. A mente (mundo 2, realidade imaterial) é distinta do cérebro (mundo 1), mas está em relação com ele. Se a mente se identificasse com o cérebro (ou com o corpo), como defendem os materialistas fisicistas, um transplante de cérebro significaria um transplante da mente e do eu. Isto seria uma possibilidade bizarra. A mente não é uma propriedade privada do cérebro. O "cérebro é possuído pelo 'eu' e não o contrário. O eu ativo, psicofísico, é o programador ativo do cérebro, ele é o executor cujo instrumento é o cérebro" (POPPER; ECCLES, 1991, p. 159). Com estas posições reflexivas, Popper, semelhante a Bunge, se mostra contrário ao reducionismo ontológico (ou fisicista) e epistemológico.

Depois de tratar do surgimento da mente, Popper reflete sobre a sua natureza. A mente é o eu autoconsciente. "Nós não só temos consciência de estarmos vivos, mas cada um de nós tem consciência de ser um 'eu'; consciência da sua identidade através de um considerável período de tempo" (POPPER; ECCLES, 1991, p. 136). Para o filósofo austríaco, a mente ou o eu é uma entidade dinâmica, autoconstrutiva, encarnada (apesar de transcender o puramente físico) e autoconsciente. O eu (ou a mente) se constitui, de modo dinâmico, através da relação com os outros, com os "tus" circundantes, por meio da sociabilidade e da linguagem. "O que caracteriza o eu [...] é que todas as nossas experiências estão estreitamente relacionadas e integradas; não somente com experiências passadas, mas também com os nossos programas de ação mutáveis, nossas expectativas 
e nossas teorias" (POPPER; ECCLES, 1991, p. 190). Este eu dinâmico e interativo é uma realidade encarnada, isto é, pressupõe a existência de uma realidade física (matéria, cérebro, corpo) e, simultaneamente, a transcende. A "consciência humana do ' $\mathrm{eu}^{\prime}$ ' transcende os pensamentos puramente biológicos” (POPPER; ECCLES, 1991, p. 187). Esta consciência é autoconsciente. Um dos milagres do processo evolutivo se refere ao "surgimento da completa consciência, capaz de autoreflexão, que parece estar ligada ao cérebro humano" (POPPER; ECCLES, 1991, p. 169).

O dualismo interacionista de Popper refuta a redução fisicista do ser humano, defendida pela teoria da identidade. A mente é uma entidade imaterial, mas encarnada e gerada pelo processo evolutivo que produz novas realidades, as quais supõem as realidades anteriores e supera-as. A novidade é emergente daquilo que já existe. A emergência está latente na realidade existente de modo que ela é apenas exteriorizada. Até aqui a antropologia de Popper, excetuando a visão imaterial da mente, tem uma proximidade com a de Bunge. A concepção antropológica de Popper sobre a relação mente-cérebro é dualista visto que a relação entre as ambas magnitudes é puramente dinâmica e de tendência extrínseca.

A apresentação da vertente filosófica da teoria dualista interacionista defendida por Popper é referendada pelo neurólogo australiano John Carew Eccles (1903-1997), o qual parte da fisiologia e da anatomia cerebrais. A vertente filosófica ganha uma fundamentação neurológica, ou seja, um apóio empírico. Eccles defende a teoria popperiana dos três mundos e o dualismo interacionista da relação mente-cérebro. O filósofo e o neurólogo se divergem em dois pontos: a emergência do eu consciente (para o filósofo se dá a partir da evolução gradual da matéria; para o neurólogo é um dado criacionista, um fator transcendente) e sua imortalidade (negada pelo filósofo e defendida pelo neurólogo) (RUIZ DE LA PEÑA, 1983, 148-152) 5 .

A visão do dualismo interacionista sobre a mente tem uma proximidade com a explicação emergentista de Bunge. $O$ dualismo compreende o ser humano como uma magnitude composta de duas substâncias, ontologicamente, independentes, heterogêneas e autônomas. O ser humano é constituído por duas camadas: uma material (cérebro) e outra imaterial (mente). Ele é o resultado da justaposição de duas substâncias extremas, irredutíveis e divergentes. A tese popperiana da relação mente-cérebro tem uma semelhança com o dualismo platônico da relação corpo-alma. O cérebro (o corpo), em termos cartesianos, é visto como a res extensa, um mecanismo dirigido pela res cogitans. A mente (o espírito) parece ser reduzida à condição de espírito de uma máquina. O dualismo popperia-

\footnotetext{
${ }^{5}$ Eccles não é o único neurólogo a defender uma visão dualista sobre a relação mente-cérebro. Outros neurólogos também preconizam esta perspectiva, dentre os quais: Charles Sherrington (1857-1952), Wilder Penfield (1891-1976) e Roger W. Sperry (1913-1994).
} 
no compreende a relação entre a mente e o cérebro de forma extrínseca e dinâmica.

\subsection{A posição dos cibernéticos: a mente é o cérebro o qual é uma máquina}

A visão dos cibernéticos é uma versão empírica da teoria da identidade: homem = cérebro = máquina . O ser humano é o seu cérebro o qual, por sua vez, é uma central processadora de informação. Para os cibernéticos, há uma analogia entre o funcionamento biológico do cérebro humano e o funcionamento mecânico de uma máquina. Em outros termos, há uma semelhança entre o natural e o artificial. A afirmação segundo a qual o ser humano é o cérebro significa que a sua atividade e o seu comportamento são fruto da interação de mecanismos neuronais que permutam, processam e controlam a informação. A base biológica destes processos está relacionada com uma base física. A máquina cibernética deseja não só igualar, mas também superar a máquina natural do cérebro. Assim, postula-se que o homem é igual à máquina. Para os cibernéticos, entre a inteligência natural do cérebro humano e artificial da máquina não há uma diferença qualitativa. Os mecanismos neuronais podem ser duplicados em mecanismos eletrônicos. Deste modo, para os cibernéticos, a evolução biológica chegou à conclusão e iniciou-se o ciclo evolutivo tecnocientífico. Estaria ocorrendo a passagem do pólo evolutivo natural para o artificial, isto é, a passagem do homo sapiens sapiens ao homo sapiens cyberneticus (RUIZ DE LA PEÑA, 1994, p. 80-81). Entre os principais representantes da corrente cibernética estão o físico escocês Donald M. MacKay (1922-1987), o físico espanhol Luis Ruiz de Gopegui (1929-) e cientista estadunidense Marvin L. Minsky (1927-).

O fundamento antropológico do pensamento cibernético (homem = cérebro = máquina) está na, já exposta, teoria da identidade pisconeural. A lógica do discurso monista e fisicista de $\mathrm{H}$. Feigl já antecipou uma homologação entre o ser humano e a máquina. Feigl defende que a mente é o cérebro, o qual é uma entidade física regida por leis físicas e dotado de propriedades físicas. Para Feigl, o cérebro é o mecanismo responsável por todas as ações humanas (comportamento, liberdade, escolhas). As idéias de Feigl conduzem espontaneamente à comparação entre o ser humano e a máquina e vice-versa. Fiegl acredita na possibilidade de que futuramente surjam estruturas mecânicas capazes de pensar e de sentir. A antropologia do materialismo fisicista está orientada para uma percepção cibernética do humano. Esta antropologia conduz a uma série de equações: homem $=$ mente; mente $=$ cérebro; cérebro $=$ máquina; homem $=$ máquina $^{6}$.

\footnotetext{
${ }^{6}$ Para uma exposição das principais ideias dos autores que foram os pioneiros na homologação entre o homem e máquina conferir: RUIZ DE LA PEÑA, 1994, p. 92-97.
} 
Um dos principais representantes da corrente cibernética, o físico espanhol, Ruiz de Gopegui, defende a homologação entre o homem e a máquina. O ser humano é visto como um autômata consciente e a máquina como um sujeito artificial. $\mathrm{O}$ pensamento de Gopegui consiste numa afirmação radicalizada do monismo fisicista e, por consequência, na rejeição do dualismo e de qualquer outra versão do materialismo (emergentista e outros).

Gopegui advoga uma homologação entre a mente e o cérebro e entre o cérebro e a máquina. "As investigações neurofisiológicas dos últimos trinta anos demonstram de uma forma clara que as hipóteses anteriores [sobre a natureza da mente] são inaceitáveis" (GOPEGUI, 1983, p. 115). "Na atualidade, caso se analise o que é a mente [...] não resta outro remédio que admitir que se trata de um processo material [...] Os processos mentais [...] processos de elaboração de informação, são autênticos processos físicos" (GOPEGUI, 1983, p. 148). Partindo de um ponto de vista estrutural, "os processos cósmicos, biológicos e mentais são da mesma natureza" (GOPEGUI, 1983, p. 148). A inteligência natural do ser humano e a inteligência artificial da máquina são produtos direto da física, ou seja, estão submetidos às mesmas leis e funcionam de acordo com os mesmos mecanismos. Neste sentido, pensar seria simplesmente um processo físico-químico. Citando Thomas H. Huxley, Gopegui conclui sua percepção cibernética sobre o ser humano: "somos autômatas conscientes" (GOPEGUI, 1983, p. 148. 166). A máquina é, pelo menos em potencial, uma autômata pensante. Desta forma, a autoconsciência não é um privilégio exclusivo do ser humano. "As máquinas inteligentes de manhã [...] serão de certo modo conscientes, no sentido de que poderão saber o que querem fazer e porque querem fazer" (GOPEGUI, 1983, p. 50-51). Assim, a autoconsciência é vista somente como um tipo de conhecimento abstrato que para ser adquirido necessita apenas de aperfeiçoar a aptidão para as atividades abstratas que as máquinas já possuem, ainda que em dimensões modestas. Munida de autoconsciência, a inteligência artificial tem acesso, de modo análogo ao ser humano, ao campo da subjetividade. Assim, as inteligências (autoconsciência) natural e a artificial compartilham, ainda que em níveis diferentes, de uma qualidade subjetiva. A máquina é elevada à condição de sujeito, detentora de uma autoconsciência artificial, e o sujeito é reduzido à condição de máquina (GOPEGUI, 1983, p. 134).

O processo da conquista da autoconsciência subjetiva, por parte da máquina, tem como elemento imprescindível o mecanismo de aprendizagem. Segundo Gopegui, nada se opõe ao fato das máquinas, que já são equipadas de memória, terem acesso a um processo educacional e de aprendizagem. A máquina, assim como uma criança, pode ser iniciada num processo educacional. Assim como se pode educar um ser humano, também pode-se educar um máquina para executar determinados mecanismos. "As diferentes etapas que compõem um processo de aprendizagem são todas operações que estão ao alcance de nossos modestos computadores eletrô- 
nicos" (GOPEGUI, 1983, p. 125). Destarte, as máquinas adquiririam "sua própria personalidade", podendo gozar de atributos que, até então, eram exclusivos dos seres humanos como, por exemplo, a liberdade e a vontade (GOPEGUI, 1983, p. 25-26). No horizonte de Gopegui, a racionalidade, a aprendizagem, a autoconsciência, a subjetividade e a personalidade que eram prerrogativas exclusivas dos seres humanos seriam, também, acessíveis às máquinas (as inteligências artificiais). É possível que no futuro, na era da "idade da inteligência artificial", surjam computadores inteligentes ("máquina sapiens"), que munidos de uma capacidade de aprendizagem poderão superar a inteligência de seu criador (GOPEGUI, 1983, p. 54). Segundo Gopegui (1983, p. 164), todos os aspectos relevantes do pensamento e da conduta humana são formalizáveis, isto é, redutíveis a uma formulação algorítmica que possa ser dirigida pela máquina. Dentre estes aspectos, na visão do espanhol, é necessário excetuar dois: os sentimentos e a reprodução. "É nisso e somente nisso que o homem se diferencia das máquinas" (GOPEGUI, 1983, p. 135). O homem-sujeito é uma simples etapa do processo ascendente da máquina-sujeito.

Portanto, a liberdade, a vontade, a responsabilidade, a capacidade de escolher, de eleger e de decidir, as atividades permeadas de um teor ético, social e político, não seriam mais operações exclusivamente do ser humano. As máquinas seriam capazes de realizar atividades que, anteriormente, eram próprias dos humanos. Os direitos humanos dos homens corresponderiam ao direito de uma programação correta das máquinas. Isto significaria a derrocada do mito da centralidade, da superioridade e autonomia do ser humano, em relação aos demais seres (GOPEGUI, 1983, p. 56). Segundo Gopegui, o autonomocentrismo, a crença de que o ser humano é livre e autônomo consiste na última barreira a ser derrubada pelas ciências. Assim como o paradigma geocêntrico foi substituído pelo heliocêntrico, o antropocêntrico, iniciado com René Descartes, foi superado pelas ideias evolucionistas de Darwin, o autonomocêntrico está destinado a ser superado pela cibernética (máquinas inteligentes) (GOPEGUI, 1983, p. 194-197). Deste modo, se evidenciará que "o nosso cérebro não seria mais que uma máquina” (GOPEGUI, 1983, p. 197). A mente é o cérebro, o qual é uma máquina.

No subterrâneo da visão cibernética do humano, patrocinada por Ruiz de Gopegui, está uma demolição de qualquer forma de humanismo. O ser humano não gozaria de praticamente nenhum atributo que o distinguiria das demais realidades espaço-temporais. $\mathrm{O}$ mito da liberdade, da ética, da autonomia, como potencialidades que distinguiam o ser humano do seu entorno, teria chegado ao seu fim. Uma vez consumada a operação de desconstrução do mito da superioridade do ser humano, a próxima etapa seria promover uma inversão na ordem de precedência: em primeiro lugar estaria a máquina e depois o ser humano. Antes, o ser humano tinha uma proeminência sobre a máquina e a realidade, mas, no futuro, a máquina 
será superior, ocupará a centralidade do real e o ser humano será lançado à margem da significação. $\mathrm{O}$ ser humano será um servidor das máquinas; se precipitará da qualidade de sujeito e se tornará um objeto. Especula-se sobre a possibilidade das máquinas inteligentes, futuramente, assumirem o controle da realidade, chegando a se apoderar, inclusive, do mundo da política (GOPEGUI, 1983, p. 54-55). Chegará o dia em que uma nova geração de computadores imporá as leis as quais o ser humano deverá se submeter e seguir. No futuro, "o ser humano se converterá em 'menino de recados' dos robôs do futuro" (GOPEGUI, 1983, p. 55). O ser humano se tornará refém de um mundo (dos objetos, das máquinas) que ele mesmo criou. Ele viverá sob a ditadura da máquina inteligente. "Em um futuro não muito distante, os seres racionais já não serão indispensáveis para realizar trabalhos de ordem intelectual" (GOPEGUI, 1983, p. 57).

Uma consequência da visão cibernética do humano, a partir da leitura do espanhol, é o eclipse da dimensão ética. Se o ser humano não é livre, autônomo e nem sujeito, logo, também, não é responsável por suas ações. A ética seria absorvida pela sociologia, pela psicologia, as quais seriam reduzidas à biologia e todas seriam reduzidas à física. As ciências para terem plausibilidade deverão ser regidas por leis físicas. A pergunta que deverá ser feita, futuramente, não é se um comportamento é bom ou mau, "mas se está bem ou mal programado" (GOPEGUI, 1983, p. 189)7.

A proposta dos cibernéticos produz dificuldades de ordem filosófica, ética e teológica. No plano filosófico, as observações feitas à teoria da identidade de Feigl podem ser aplicadas à visão dos cibernéticos, no que tange à relação mente $=$ cérebro $=$ estrutura física (máquina). $\mathrm{O}$ programa cibernético da homologação homem-máquina tem que se confrontar com uma árdua e problemática questão filosófica: o reducionismo ontológico e epistemológico.

Uma variante do problema reducionista é a especulação sobre a possibilidade de uma formalização de toda conduta humana inteligente. Quem afirma que esta tese é possível de ser realizada está assumindo uma postura reducionista, isto é, está defendendo que o qualitativo (o humano) pode se expressar de modo quantitativo, através de equações lógico-matemáticas. Quem sustenta que esta tese é irrealizável defende que algumas funções da mente humana (estéticas, éticas etc.) não podem ser expressas de forma quantitativa e matemática. A conduta humana é imprevisível e não pode ser reduzida a uma codificação numérica e matemática. A conduta está ligada à inteligência e à consciência humanas, duas grandezas que não estão sujeitas aos procedimentos matemáticos.

\footnotetext{
${ }^{7}$ Sobre a homologação homem-máquina, M. Minsky tem uma visão mais moderada e comedida, em relação à posição radical e eufórica de Gopegui. Para uma síntese das ideias de Minsky conferir: RUIZ DE LA PEÑA, 1994, p. 102-104.
} 
A antropologia monista e fisicista da teoria da identidade psiconeural sobre a qual está apoiada a posição dos partidários da inteligência artificial, defendida pelos cibernéticos, se degringola numa posição dualista. O histórico binômio corpo-alma corresponderia, atualmente, ao binômio software-hardware. A histórica supremacia da alma sobre o corpo seria traduzida, hoje, pelo primado do software (conteúdos do cérebro) sobre o hardware (suporte físico dos conteúdos cerebrais). Deste modo, a questão mais relevante seria o conteúdo cerebral (software) e não propriamente a sua encarnação material (hardware) (RUIZ DE LA PEÑA, 1994, p. 107-109).

No plano ético, caso fosse possível ter acesso aos conteúdos cerebrais de uma pessoa, mediante um dispositivo eletrônico, seria possível clonar a sua consciência e o seu eu. Assim, se poderia reproduzir de modo ilimitado os conteúdos cerebrais pessoais. Na realidade, seria possível especular sobre a clonagem da consciência de um ser humano? Como uma consciência individual poderia estar simultaneamente em vários lugares? Os "eus" reproduzidos (as cópias) teriam a mesma autenticidade do que o "eu" original? As noções de "eu" e de "consciência" seriam substituídas pelas de um sistema operacional, sistema de controle, software? O que está em questão no subsolo destas interrogações é a individualidade, o valor e a irrepetibilidade de cada pessoa humana.

Os cibernéticos ao reduzirem o ser humano ao nível do maquinal terminam por destituí-lo do seu primado onto-axiológico, em relação aos demais entes. O ser humano não diferiria em nada, do ponto de vista qualitativo, dos demais entes. Na visão cibernética, o ser humano não seria superior à máquina, do ponto vista ontológico, axiológico e nem operativo. Se o ser humano não é mais e nem vale mais do que uma máquina, então onde está o sentido do seu viver e em que reside sua dignidade? Os cibernéticos defendem uma leitura anti-humanista do ser humano e uma leitura humanista da máquina. As antropologias anti-humanistas (cibernéticos e identidade psiconeural) estão permeadas de sérias questões de ordem ética, social e política (manipulação genética, controle psicológico, formatação funcional do cérebro e outros). Os cibernéticos fazem uma inversão: arrancam o primado do ser humano sobre a realidade para conferi-lo à máquina. O ser humano seria destituído do seu primado histórico sobre a realidade por um instrumento criado por suas mãos. A criatura (a máquina) ocuparia o lugar do criador (o ser humano). Deste modo, o ser humano seria visto simplesmente como uma etapa, um meio e um valor relativo no processo ascendente que culmina na máquina inteligente. Se o ser humano é igual a uma máquina, como sustentam os cibernéticos, então qual seria a diferença entre matar uma pessoa e destruir um robô?

No plano teológico, para a antropologia cristã, o reconhecimento de que o ser humano é uma magnitude qualitativamente superior à máquina e a qualquer outra realidade mundana é um dado irrenunciável e inegociá- 
vel. O ser humano, como imagem do Deus, tem um primado ontológico e axiológico sobre todas as realidades criadas. Em outros termos, o ser humano ocupa um duplo cume: da pirâmide da realidade e da escala de valores da realidade. O ser humano é mais e vale mais do que qualquer outra criatura porque possui um fundamento espiritual e pessoal. Ele é fim e não meio; valor absoluto e não relativo; realidade transcendente e não imanência pura.

\section{Considerações finais}

As antropologias materialistas anti-humanistas (identidade psiconeural, cibernéticos e outras) despojam o ser humano de sua singularidade e onto-axiologia, reduzindo-o a uma realidade mundana como qualquer outra. $\mathrm{O}$ ser humano é visto como mais um ente entre os outros entes destituído de qualquer particularidade. Ele é simplesmente mais uma peça que compõe a engrenagem do real. Estas antropologias concebem a realidade de forma homogênea, em sua textura onto-axiológica. Assim, o ser humano tem a mesma "dignidade" e o mesmo "valor" do que um animal, uma planta ou uma máquina. Há uma homologação onto-axiológica do real. O ser humano é visto como um meio e um valor relativo. A ética, a liberdade, a dignidade e outros atributos próprios do ser humano são eliminados. O ser humano passa da condição de sujeito e à de objeto; de magnitude existencial à matéria que ocupa espaço no cenário cósmico. Ele é reduzido à sua condição biológica, animal, imanente e horizontal.

Diante deste cenário humanamente desconsolador, as antropologias humanistas ( como, por exemplo, antropologia cristã e emergentismo) concebem o ser humano como uma uni-totalidade anímico-corpórea. Esta concepção está ligada à singularidade, à ontologia e à axiologia do ser humano. Isto significa que ser humano possui uma centralidade mundana porque é e vale mais do que qualquer outro ente. O ser humano é revestido de uma dimensão pessoal, espiritual e qualitativa que o torna um ser supremo, em relação à qualquer outro do mapa ontológico. Por sua dimensão onto-axiológica, o ser humano se destoa do seu entorno material. O ser humano ocupa o climax da pirâmide onto-axiológica do real. Esta posição deve fazê-lo perceber que é ornado, por sua condição de imagem de Deus, de uma responsabilidade cuidadora e administradora na relação com as demais criaturas. O ser humano é detentor de uma singularidade pessoal que o torna irredutível a qualquer outra realidade espaço-temporal. $\mathrm{O}$ ser humano é um valor absoluto, um fim não mediatizável, uma magnitude irrepetível, singular e única.

A antropologia cristã (e outras de inspiração humanista), refletindo sobre a relação corpo-alma do ser humano, pronuncia um sonoro "não" diante 
do reducionismo ontológico e epistemológico de algumas antropologias materialistas anti-humanistas. No subterrâneo deste uníssono "não" está uma percepção psicofísica do ser humano, enquanto expressão de sua singularidade e de sua onto-axiologia.

\section{Referências}

AGOSTINHO. A Cidade de Deus. 2 ed. Petrópolis: Vozes, 1990. v. 2.

BARTH, K. Dogmatique. La doctrine de la creation. Genève: Labor et fides, 1961. v. III/2.

BUNGE, M. El problema mente-cerebro. Un enfoque psicobiológico. 3 ed. Madrid: Tecnos, 2011.

CANOBBIO, C. O destino da alma. Loyola: São Paulo, 2012.

DENZINGER, H.; HÜNERMANN, P. Compêndio dos símbolos, definições e declarações de fé e moral. São Paulo: Paulinas, 2007.

FIORENZA, F.P.; METZ, J.B. O homem como união de corpo e alma. In: FEINER, J.; LOEHRER, M. (Eds.). Mysterium Salutis. Petrópolis: Vozes, 1973. v. II/3, p. 27-72.

FLICK, M.; ALSZEGHY, Z. Antropología Teológica. 8 ed. Salamanca: Sígueme, 1999.

GOPEGUI, L.R. Cibernética de lo humano. Madrid: Tecnos, 1983.

HUGO DE SÃO VÍTOR. De sacramentis christianae fidei. In: MIGNE, J.P. Patrologia Latina (Documenta Catholica Omnia), 1854. v. 176.

LADARIA, L. Introdução à antropologia teológica. São Paulo: Loyola, 1998.

LADARIA, L. O homem criado à imagem de Deus. In: SESBOÜÉ, B. (Dir.). História dos dogmas. O homem e sua salvação: séc. V-XVII. São Paulo: Loyola, 2003. v. 2, p. 87-132.

MERLEAU-PONTY, M. Phénoménologie de la perception. Paris: Gallimard, 1945.

MOLTMANN, J. Deus na criação. Doutrina ecológica da criação. Petrópolis: Vozes, 1993.

POPPER, K.; ECCLES, J.C. O eu e seu cérebro. Brasília: Universidade de Brasília, 1991.

RAHNER, K. Para una teología del símbolo. In: . Escritos de teología. 4. ed.

Madrid: Taurus, 2002. v. 4, p. 261-294.

RUBIO, A.G. Unidade na pluralidade. 3. ed. São Paulo: Paulus, 2001.

RUIZ DE LA PEÑA, J.L. As Novas Antropologias: Um desafio à teologia. São Paulo: Loyola, 1983.

RUIZ DE LA PEÑA, J.L. Mentes, cerebros, máquinas. Communio, Sevilla, v. 9, n. 3, p. 211-223, 1987. 
RUIZ DE LA PEÑA, J.L. Imagen de Dios. Santander: Sal Terrae, 1988.

RUIZ DE LA PEÑA, J.L. Teologia da criação. Loyola: São Paulo, 1989.

RUIZ DE LA PEÑA, J.L."Homo cyberneticus"? Antropología e inteligencia artificial. In: DE SAHAGÚN LUCAS, J. Nuevas antropologías del siglo XX. Salamanca: Sígueme, 1994, p. 79-112.

TOMÁS DE AQUINO. Suma Contra los Gentiles. Madrid: Catolica, 1952. v. 1.

TOMÁS DE AQUINO. Suma teológica. São Paulo: Loyola, 2002.

ZUBIRI, X. Sobre el hombre. Madrid: Alianza, 1986.

WOLFF, H.W. Antropologia do Antigo Testamento. São Paulo: Loyola, 1975.

Renato Alves de Oliveira é graduado em filosofia (1998) e teologia (2002) pela PUC Minas, mestre em teologia (2006) pela FAJE e doutor em teologia dogmática (2011) pela Pontifícia Universidade Gregoriana de Roma. É professor adjunto do departamento de teologia da PUC Minas e pesquisador de temas como a morte nos âmbitos cultural, filosófico e teológico. Também estuda as relações entre antropologia e escatologia cristãs.

Endereço: Praça da comunidade, 90 (casa)

Bairro Dom Cabral

30535-210 Belo Horizonte - MG

praobh@yahoo.com.br 
